\title{
Ambient air quality monitoring in southern Kuwait
}

\author{
A. A. Ramadan, A. Khan \& S. Al-Hajraf \\ Coastal and Air Pollution Department, \\ Institute for Scientific Research, Kuwait
}

\begin{abstract}
Ambient air quality monitoring was conducted at twenty locations in the southern part of Kuwait as part of an environmental impact assessment study requested by the Kuwait National Petroleum Company. Two waves of passive samplers (triplicates) were used to measure: $\mathrm{NO}, \mathrm{NO}_{2}, \mathrm{SO}_{2}, \mathrm{H}_{2} \mathrm{~S}, \mathrm{NH}_{3}$ and a high volume sampler was used to measure PM10. During the sampling period, the wind was observed to be predominately from the west and northwest with an average speed of $4.28 \mathrm{~m} / \mathrm{s}$. A comparison between the measured concentrations and the applicable air quality standards promulgated by the Kuwait Environment Public Authority showed that those compounds had very low concentrations compared to both industrial and residential KEPA standards and accordingly there is no violation of KEPA air quality standards.
\end{abstract}

Keywords: passive samplers, air pollution, PM10.

\section{Introduction}

The Kuwait National Petroleum Company (KNPC) requested that the Kuwait Institute for Scientific Research (KISR) conduct a baseline Environmental Impact Assessment (EIA) study for building the fourth refinery in Az-Zour area in the southern part of Kuwait, which is shown in Figure 1. In this paper we report on the results of the ambient air quality monitoring part of the conducted EIA.

\section{Sampling locations}

Ambient air quality monitoring was conducted at twenty locations as shown in Figure 1. The UTM coordinates and description are listed in table 1. The 
monitoring locations include the planned New Refinery site, the coastal area adjacent to the planned marine terminal site, nearby residential areas and locations upwind and downwind of the Az-Zour North and South Power Stations (bounded by A7, A8 and A9).

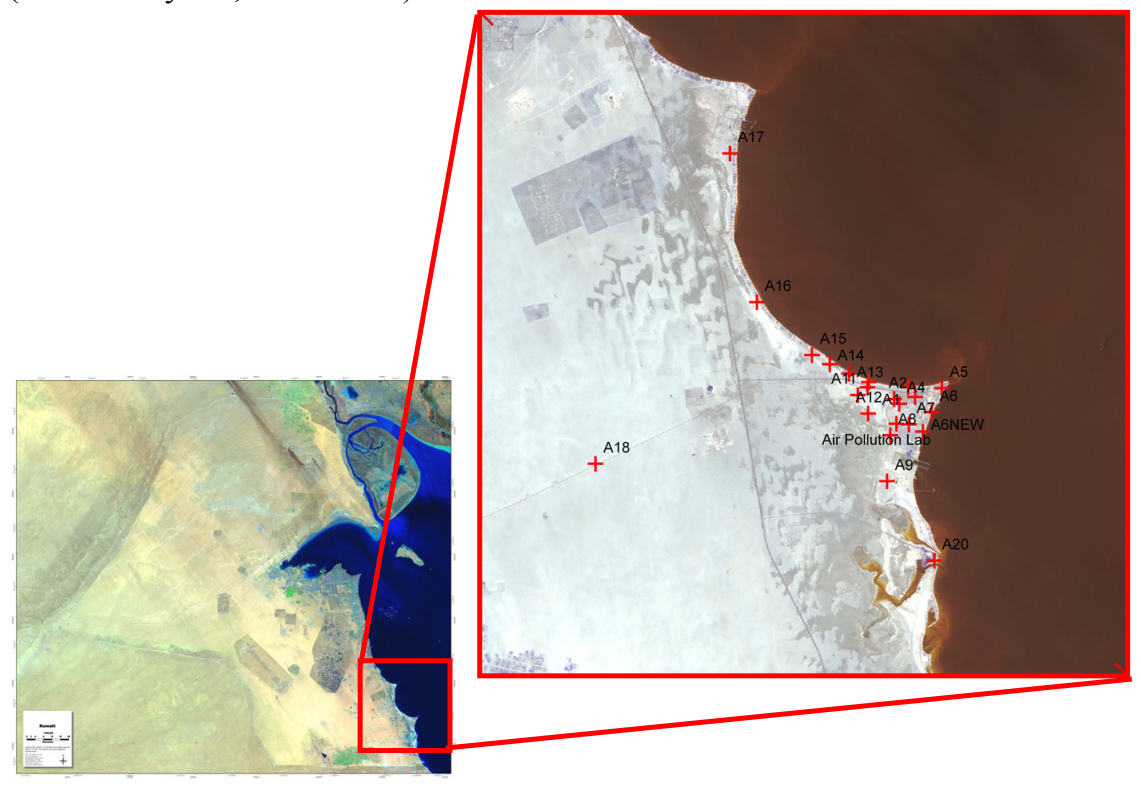

Figure 1: Locations of ambient air quality monitoring.

\section{Monitoring techniques}

Passive samplers (triplicates - refer to Figure 2) were used at twenty locations to measure the following components: $\mathrm{NO}, \mathrm{NO}_{2}, \mathrm{SO}_{2}, \mathrm{H}_{2} \mathrm{~S}$ and $\mathrm{NH}_{3}$. The samplers were secured to existing structures or on temporary supports. The samplers were deployed using a PVC rain shelter and incorporated support clips provided by the manufacturer (IVL Swedish Environmental Research Institute Ltd Gothenburg, Sweden). Even in the absence of rain, the shelter is required to minimise dust contamination and the effects of advection on the diffusive samplers. Based on the passive samplers manufacturer's advice, the samplers were left in the field for 336 hours. Prepared samplers were transported to and from the field in air-tight containers, and minimally handled in the field using latex gloves. The passive samplers were then sent to IVL for analysis. Passive samplers were installed in two waves between 26/10/2005 and 24/11/2005.

During the sampling period, the meteorological conditions, e.g. wind speed and direction, relative humidity, precipitation, atmospheric pressure and temperature, were monitored using portable weather stations. The wind was observed to be predominately from the west and northwest with an average speed of $4.28 \mathrm{~m} / \mathrm{s}$. From the windrose plot shown in Figure 3, it can be seen that 
$14 \%$ of the measured wind had an angle of $259^{\circ}-281^{\circ}, 15 \%$ had an angle of $281^{\circ}-304^{\circ}, 13 \%$ had an angle of $326^{\circ}-349^{\circ}$ and $13 \%$ had an angle of $349^{\circ}-11^{\circ}$. Precipitation was recorded on 12th and 13th November 2005. The average atmospheric pressure and temperature $1014 \mathrm{~Pa}$ and $22.4^{\circ} \mathrm{C}$ respectively and the average relative humidity was $56 \%$.

Table 1: Locations of ambient air quality monitoring - based on 39 projection.

\begin{tabular}{|c|c|c|l|}
\hline Location & $\mathrm{X}$ & $\mathrm{Y}$ & \multicolumn{1}{|c|}{ Description } \\
\hline A1 & 243627 & 3182158 & Health Clinic Yard \\
\hline A2 & 242897 & 3181526 & Outside the fence of a school \\
\hline A3 & 243991 & 3181641 & The roof of the local police station \\
\hline A4 & 243163 & 3181286 & Open area close to village houses \\
\hline A5NEW & 241572 & 3182422 & Near the beach \\
\hline A6NEW & 244402 & 3179826 & Near the northeastern corner of Zour Power Station \\
\hline A7 & 243665 & 3180202 & $\begin{array}{l}\text { Approximately 200m from Az-Zour North Power Station } \\
\text { northern boundary }\end{array}$ \\
\hline A8 & 242695 & 3179628 & $\begin{array}{l}\text { Approximately 200m from Az-Zour North Power Station } \\
\text { western boundary }\end{array}$ \\
\hline A9 & 242526 & 3177219 & $\begin{array}{l}\text { Approximately 200m from Az-Zour North Power Station } \\
\text { southern boundary }\end{array}$ \\
\hline A10 & 241494 & 3182145 & New refinery boundary \\
\hline A11 & 240993 & 3181745 & New refinery boundary \\
\hline A12 & 241528 & 3180770 & New refinery boundary \\
\hline A13 & 240524 & 3182861 & Outside the first house in the beach village \\
\hline A14 & 239521 & 3183360 & $1 \mathrm{~km}$ from A13 outside the coastal houses \\
\hline A15 & 238596 & 3183844 & $2 \mathrm{~km}$ from A13 outside the coastal houses \\
\hline A16 & 235706 & 3186621 & $4 \mathrm{~km}$ from A15 outside the coastal houses \\
\hline A17 & 234296 & 3194417 & $8 \mathrm{~km}$ from A16 outside the coastal houses \\
\hline A18 & 227250 & 3178135 & $18 \mathrm{~km}$ from new refinery site, 200m away from roadside \\
\hline A20 & 245001 & 3173056 & Existing residence at Khiran Resort \\
\hline APL & 243015 & 3180239 & Inside Az-Zour North Power Station fence \\
\hline
\end{tabular}

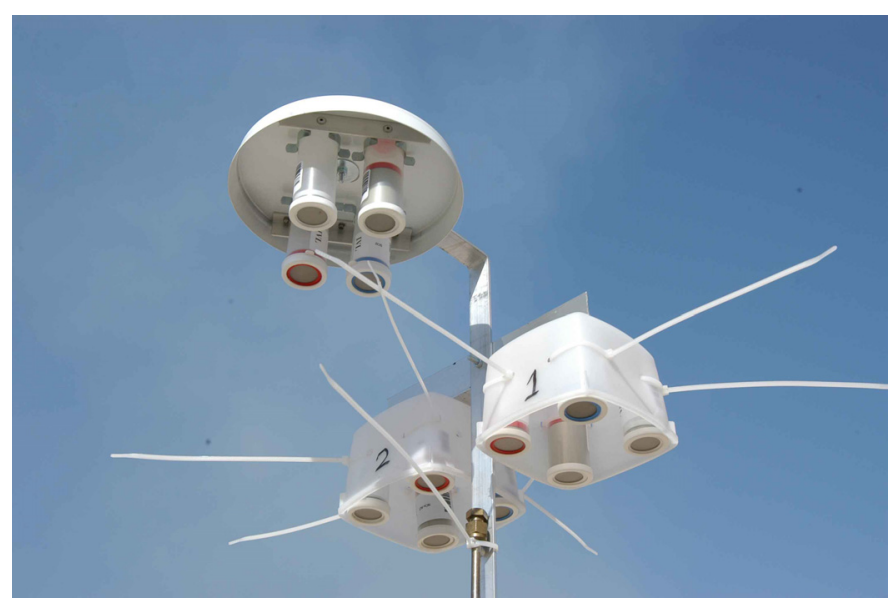

Figure 2: $\quad$ Triplicate set of the passive samplers. 
A PM10 Volumetric Flow Controlled (VFC) high volume air sampler (VFC System - Model TE-6070V, Tisch Environmental Inc. - Ohio, USA, shown in Figure 4) was used to measure the PM10 levels at four locations (A3, A13, A17 and A20). The high volume air sampler uses Micro-Quartz filter (Model: Whatman-PN 1851-865 QM-A (8 x 10 inch)) with 99.95\% particle retention $(0.3 \mu \mathrm{m})$ which is recommended for use in USEPA PM10 ambient air monitoring. The high volume air sampler was calibrated using a TE-5028 variable orifice calibrator for a pressure difference range of 12-19inch $\mathrm{H}_{2} \mathrm{O}$. At each monitoring location, the high volume air sampler was left on for nearly 24 hours and the total volume of air (actual and standard) passed through the filter was calculated to estimate the PM10 concentration.

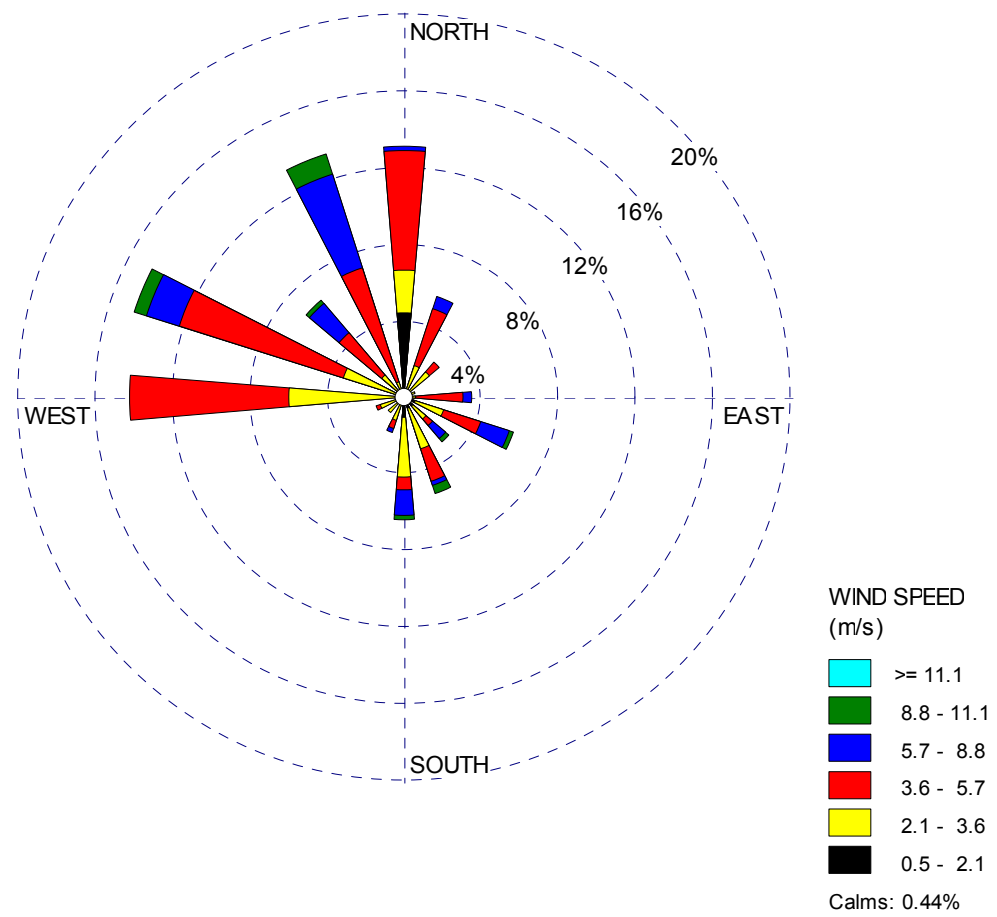

Figure 3: The windrose plot for the sampling duration. 


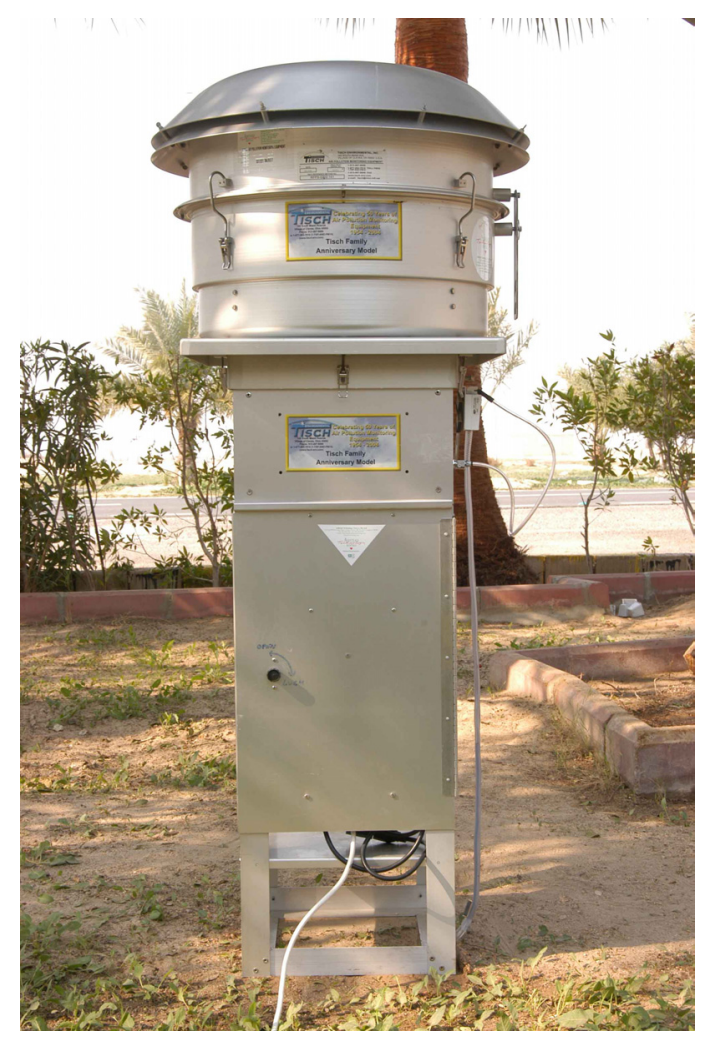

Figure 4: $\quad$ The PM10 high volume air sampler in use at A17.

\section{Results and discussion}

- The contour plots for the concentrations obtained for $\mathrm{NH}_{3}, \mathrm{NO}_{2}, \mathrm{NO}, \mathrm{SO}_{2}$ and $\mathrm{H}_{2} \mathrm{~S}$ are shown in Figures. 5-9. The PM10 concentrations are shown in Figure 10. Table 2 lists the maximum, minimum and average concentrations detected by the passive samplers.

Table 2: $\quad$ The average, maximum and minimum concentrations measured and their locations.

\begin{tabular}{|c|c|c|c|c|c|}
\hline Pollutant & \multicolumn{5}{|c|}{ Concentration $(\mu \mathrm{g} / \mathrm{m} 3)$} \\
\hline & Max & Location & Min & Location & Average \\
\hline $\mathrm{NH} 3$ & 4.43 & $\mathrm{~A} 9$ & 2.53 & $\mathrm{~A} 1 \& \mathrm{~A} 20$ & 3.35 \\
\hline $\mathrm{NO} 2$ & 18.63 & $\mathrm{APL}$ & 7.43 & $\mathrm{~A} 18$ & 14.9 \\
\hline $\mathrm{NO}$ & 14.1 & $\mathrm{~A} 20$ & 7.87 & $\mathrm{~A} 18$ & 11.48 \\
\hline $\mathrm{SO} 2$ & 16.4 & $\mathrm{~A} 3$ \& $\mathrm{A} 7$ & 10.47 & $\mathrm{~A} 17$ & 13.24 \\
\hline $\mathrm{H} 2 \mathrm{~S}$ & 7.8 & $\mathrm{~A} 18$ & 2.4 & $\mathrm{~A} 10$ & 4.53 \\
\hline $\mathrm{PM} 10$ & 90.47 & $\mathrm{~A} 17$ & 40.43 & $\mathrm{~A} 3$ & 67.93 \\
\hline
\end{tabular}


368 Air Pollution XV

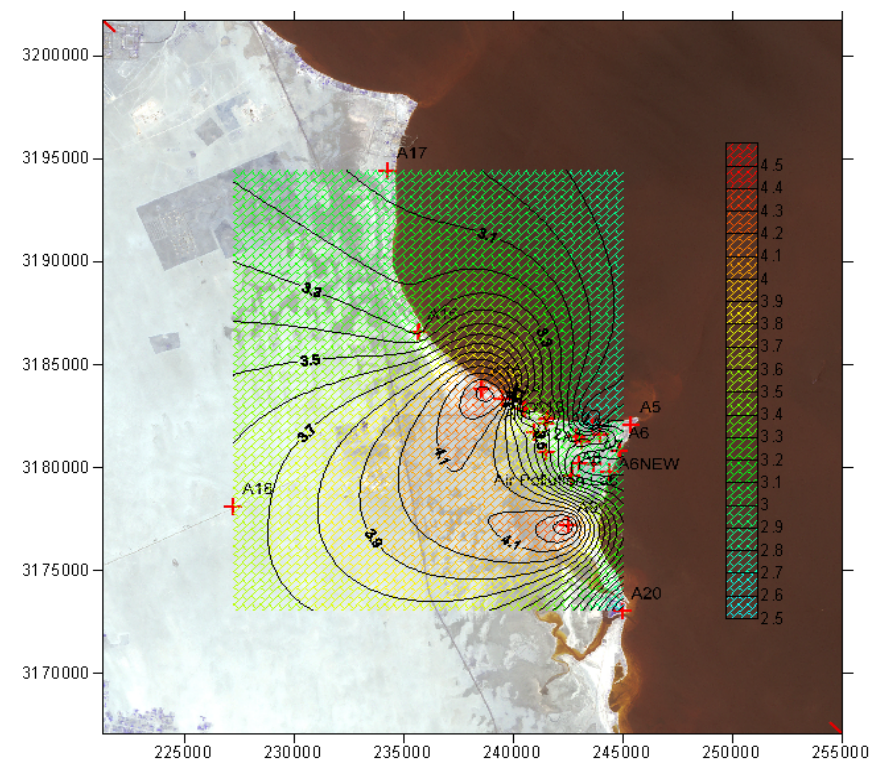

Figure 5: Showing the contour plot for the $\mathrm{NH}_{3}$ concentrations.

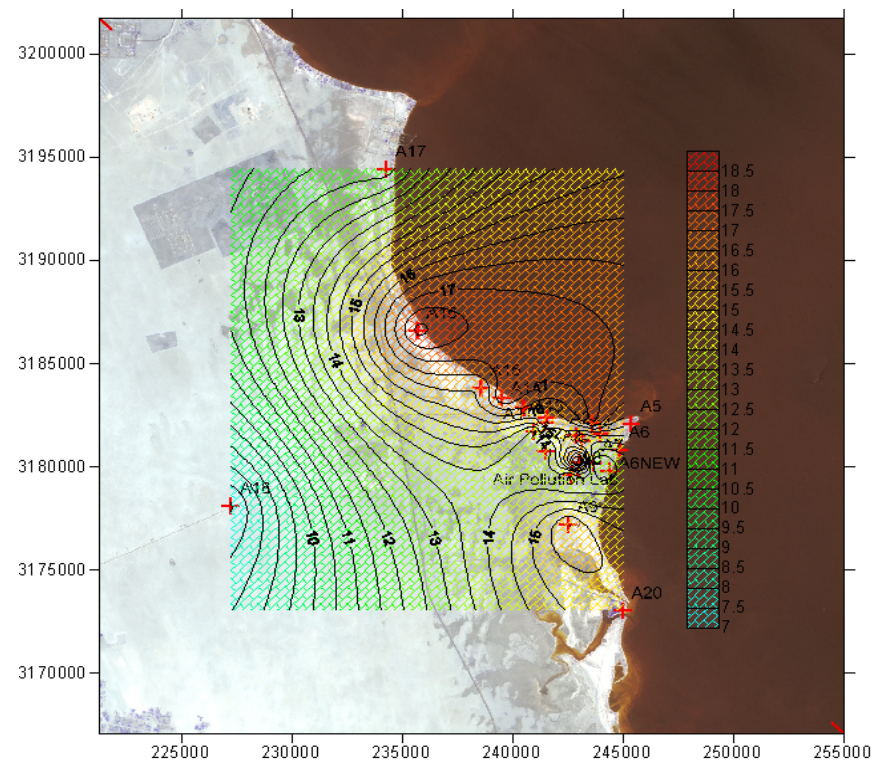

Figure 6: Showing the contour plot for the $\mathrm{NO}_{2}$ concentrations. 


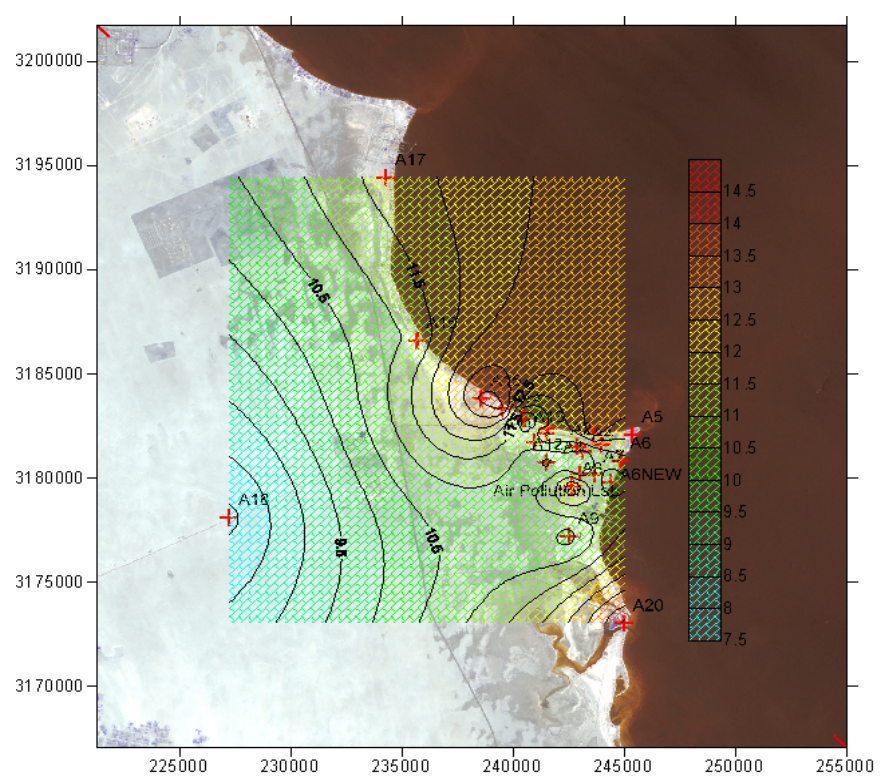

Figure 7: Showing the contour plot for the NO concentrations.

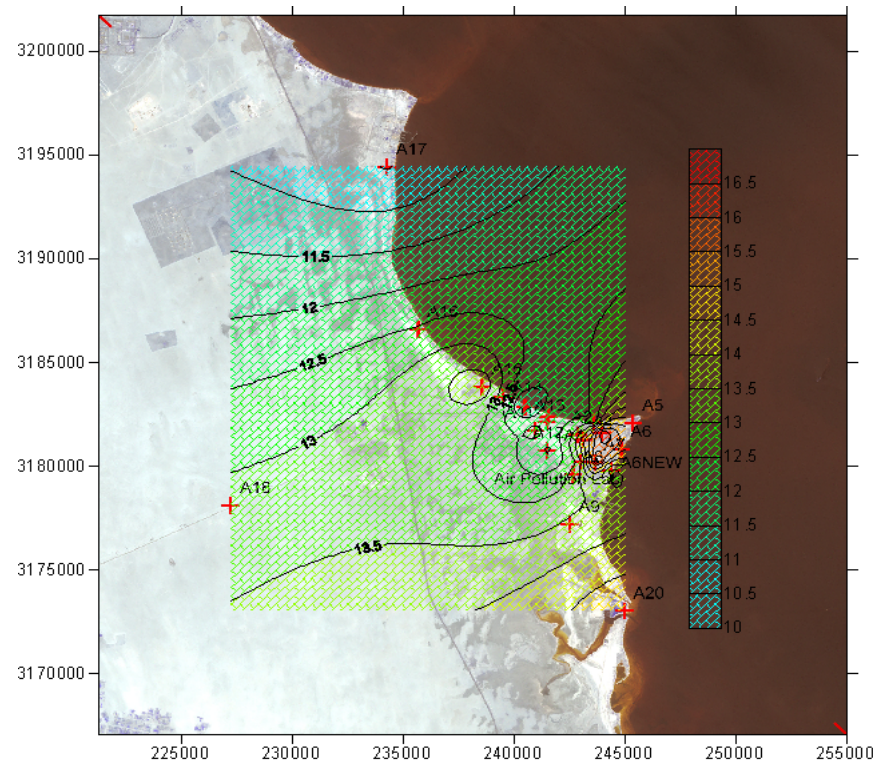

Figure 8: $\quad$ Showing the contour plot for the $\mathrm{SO}_{2}$ concentrations. 


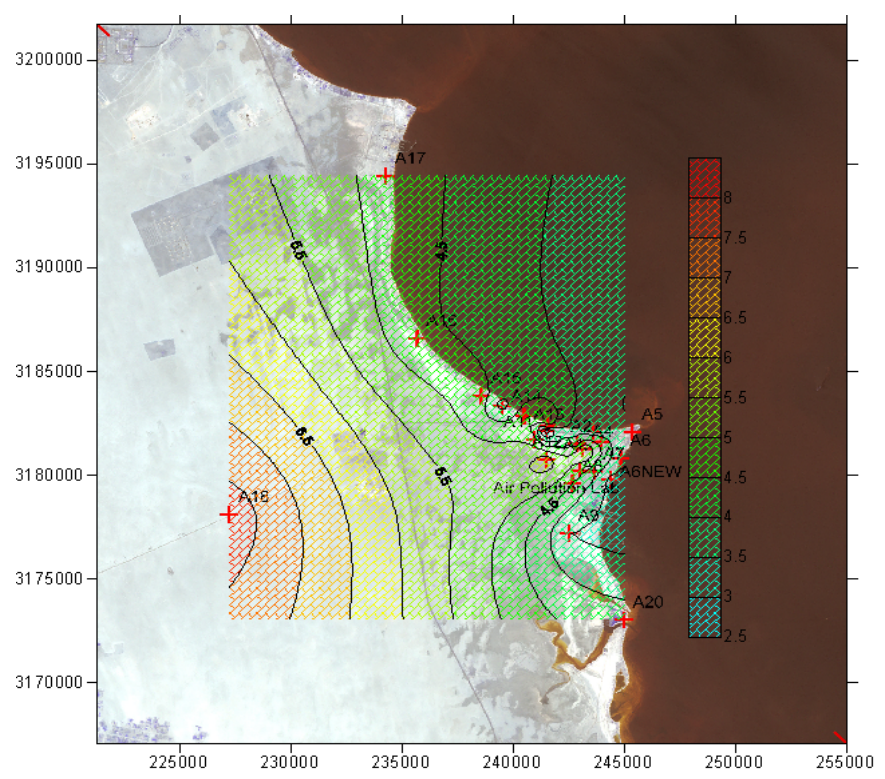

Figure 9: $\quad$ Showing the contour plot for the $\mathrm{H}_{2} \mathrm{~S}$ concentrations.

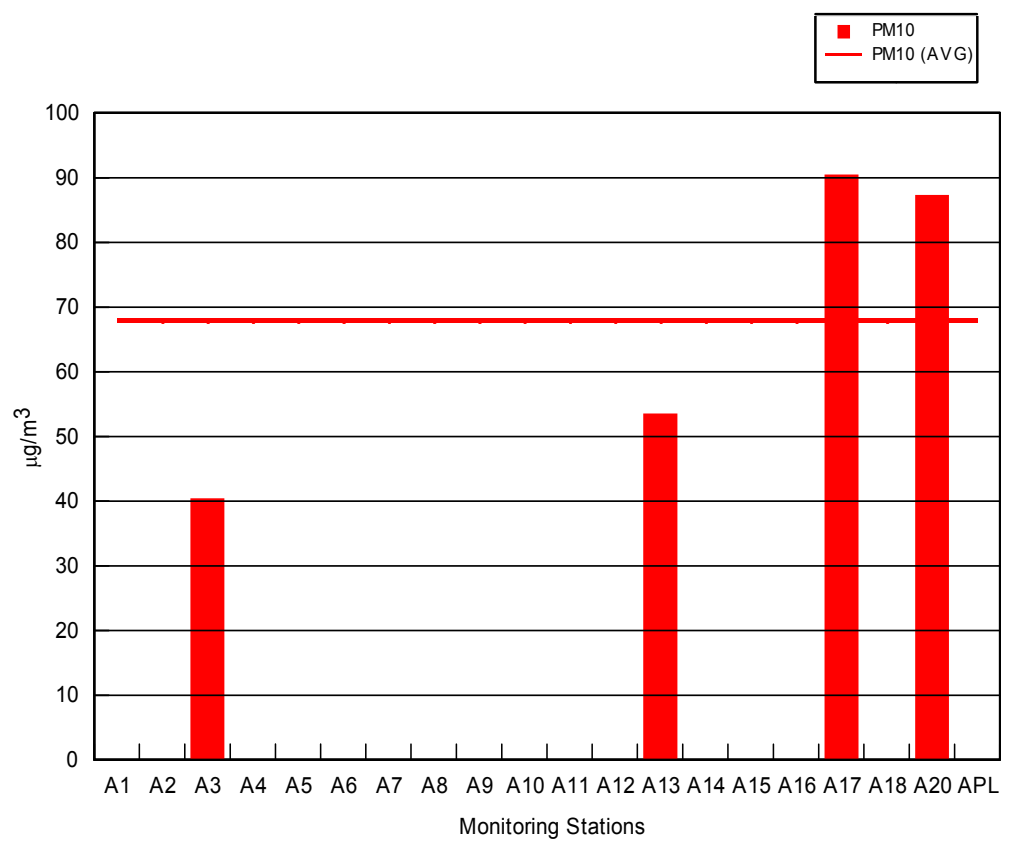

Figure 10: Distribution of the PM10 concentrations. 
$\mathrm{NH}_{3}$ concentration is highest at $\mathrm{A} 9$ and $\mathrm{A} 15$. A9 was near a landfill site while A15 was inside a farmhouse with poultry. Agricultural activities, in particular animal husbandry, are the dominant source of $\mathrm{NH}_{3}$ emissions to the atmosphere, contributing an estimated $90 \%$ of the total in Western Europe (Sutton et al [1] and Kirchmann et al [2]) and the US (Battye et al [3]). The $\mathrm{NH}_{3}$ concentration drops rather quickly as we move away from the A15 and A13.

$\mathrm{NO}_{2}$ distribution is high in the north-eastern part of the area where the car traffic is higher and it decreases gradually with distance towards the southeastern region. Low $\mathrm{NO}_{2}$ levels at A17 and A18 are indicative of the rural setting of the south-eastern part of the area. The NO distribution is similar to that of $\mathrm{NO}_{2}$ with the minimum concentration attained at A18, which is on the side of a rarely used road. The maximum NO concentration was measured at A20 near a car park inside a heavily populated resort.

The high $\mathrm{SO}_{2}$ concentration at $\mathrm{A} 3$ and $\mathrm{A} 7$ is due to oil handling and transport facilities (pipelines, pumps, etc) associated with Texaco activities. The high $\mathrm{SO}_{2}$ concentration at A20 is contributed to the plume of Az-Zour Power Stations, which is deflected under the prevailing northwesterly winds.

The $\mathrm{H}_{2} \mathrm{~S}$ concentration was highest at $\mathrm{A} 18$, which was $10 \mathrm{~m}$ from a crude oil pipeline. The PM10 measurements were not made at the same time; hence the concentration levels cannot be related to the locations. However, the high PM10 concentration at A17 can be related to the off-road driving activities on the measurements day.

A comparison between the measured concentrations and the applicable air quality standards promulgated by KEPA shows the following:

1. The maximum measured concentration $\left(4.43 \mu \mathrm{g} / \mathrm{m}^{3}\right)$ of $\mathrm{NH}_{3}$ is negligible compared to all the KEPA residential and industrial standards for $\mathrm{NH}_{3}$.

2. The maximum measured concentration $\left(18.63 \mu \mathrm{g} / \mathrm{m}^{3}\right)$ of $\mathrm{NO}_{2}$ is less than one third of the KEPA yearly standards for both residential and industrial areas for $\mathrm{NO}_{2}$.

3. The maximum measured concentration $\left(16.40 \mu \mathrm{g} / \mathrm{m}^{3}\right)$ of $\mathrm{SO}_{2}$ is about one tenth of the yearly KEPA industrial standard and one fifth of the yearly KEPA residential standard for $\mathrm{SO}_{2}$.

4. The maximum measured concentration $\left(7.80 \mu \mathrm{g} / \mathrm{m}^{3}\right)$ of $\mathrm{H}_{2} \mathrm{~S}$ is less than the yearly KEPA standard for residential areas for $\mathrm{H}_{2} \mathrm{~S}$.

5. The maximum measured PM10 concentration $\left(90.47 \mu \mathrm{g} / \mathrm{m}^{3}\right)$ is less than one third of the daily KEPA standards for both residential and industrial areas for PM10.

\section{Conclusion}

The investigation, using multipoint passive samplers, has revealed a good degree of uniformity of pollutants distribution across the region of study.

The air quality monitoring task has been completed. Field measurements relied on passive samplers and continuous monitoring equipment. For the measured compounds, it was found that they had very low concentrations compared to both industrial and residential KEPA standards, and accordingly 
there is no violation of KEPA air quality standards. The measured pollutant concentrations reflect the meteorological conditions at the time of sampling. The only location (A20) downwind of the Az-Zour power plant did not show high concentrations of $\mathrm{SO}_{2}$. It is expected that concentrations for some of the criteria air pollutants sampled, particularly for $\mathrm{SO}_{2}$, could have been significantly higher had the meteorological conditions placed the passive samplers directly downwind of the Az-Zour power plant's flue gas.

\section{References}

[1] Sutton, M.A., Place, C.J., Eager, M., Fowler, D., Smith, R.I., 1995. Assessment of the magnitude of ammonia emissions in the United Kingdom. Atmospheric Environment 29, 1393-1411.

[2] Kirchmann, H., Esala, M., Morken, J., Ferm, M., Bussink, W., Gustavsson, J., Jakobsson, C., 1998. Ammonia emissions from agriculture. Nutrient Cycling in Agroecosystems 51, 1-3.

[3] Battye, R., Battye, W., Overcash, C., Fudge, S., 1994. Development and Selection of Ammonia Emission Factors. EPA/600/R-94/190. US Environmental Protection Agency, Research Triangle Park, NC. 